\title{
Witold Wybult
}

\section{Waginizm jako przyczyna nieważności małżeństwa w świetle kan. 1084 KPK z 1983 r.}

\section{Wprowadzenie}

Zaburzenia seksualne kobiet to szeroki problem, z którym boryka się wielu specjalistów szeregu różnorakich dyscyplin, od medycyny i ginekologii począwszy, przez psychologię i seksuologię, aż na naukach prawnych, w tym prawie kanonicznym, skończywszy. Opisując zaburzenia tego typu możemy się posłużyć kontinuum, którego początkiem będą dyssatysfakcje (fizjologiczne zmiany wraz $\mathrm{z}$ emocjonalną frustracją), następnie dysfunkcje (patologiczne reakcje zarówno fizyczne jak i afektywne), kończąc na zaburzeniach seksualnych (fizycznych patologiach i dysfunkcyjności narządów seksualnych oraz zaburzeniach psychicznych) ${ }^{1}$.

Według badań i ocen specjalistów zaburzenia w sferze seksualnej dotyczyć mogą nawet 40 do 50\% kobiet, przy czym wykrywalność oraz odsetek kobiet poddawanych leczeniu jest niewielka. W wielu przypadkach osoba cierpiąca na dysfunkcję w tej sferze często nie zdaje sobie sprawy $\mathrm{z}$ istnienia nieprawidłowości lub nie jest w stanie przełamać bariery wstydu i poszukać pomocy u specjalisty.

\footnotetext{
1 Por. M. Rawińska, A. Czyżkowska, Z. Lew-Starowicz, Klasyfikacja, etiologia oraz prawidłowe diagnozowanie zaburzeń seksualnych u kobiet - ZSK (FSD - Female Sexual Disorders). Czynniki biologiczne, psychoseksualne oraz kontekstualne, Medycyna Ogólna i Nauki o Zdrowiu 4 (2012), s. 334.
} 
Problemem jest również dostęp do tych specjalistów, których jest niewielu².

Dysfunkcje seksualne obejmują różne zaburzenia, z powodu których pacjentka nie jest w stanie uczestniczyć w stosunkach seksualnych w sposób przez siebie pożądany. Może się to przejawiać spadkiem zainteresowania, brakiem zadowolenia, niedostateczną reakcją fizjologiczną niezbędną podczas stosunku czy niezdolnością do kontrolowania lub osiągania orgazmu ${ }^{3}$.

Częstym objawem, który towarzyszy kobietom w zaburzeniach seksualnych, jest ból związany ze współżyciem seksualnym, który jest zagadnieniem trudnym diagnostycznie i terapeutycznie ${ }^{4}$. Najczęściej jest on objawem osiowym dwóch głównych zaburzeń związanych z bolesnym współżyciem (dyspareunia) i pochwicy ${ }^{5}$ (vaginismus) ${ }^{6}$. Choroby te często stanowią przyczynę impotencji seksualnej u kobiet. Pochwica ${ }^{7}$, która jest zaburzeniem utrudniającym lub uniemożliwiającym stosunek seksualny ${ }^{8}$, z racji na przyczynę, może występować w dwóch odmianach: jako pochwica organiczna i nieorganiczna, czyli psychogenna.

2 Por. M. Stefankiewicz, S. ŚLĄSKi, Diagnoza zaburzeń seksualnych u kobietadaptacja testu, Studia Psychologica 10 (2010), s. 315.

3 Por. Międzynarodowa Statystyczna Klasyfikacja Chorób i Problemów Zdrowotnych, Klasyfikacja zaburzeń psychicznych i zaburzeń zachowania w ICD-10, Kraków-Warszawa 2000, s. 162.

4 Por. B. Wróbel, Current views in etiology, dignosis and the treatment of pain connected with sexual intercourse at women, Ginekologia Polska 1 (2009), s. 38.

${ }^{5}$ Warto wiedzieć, że pierwszy opis pochwicy w piśmiennictwie pojawił się w 1834 roku (Huguier), a twórcą terminu „pochwica” był amerykański ginekolog Marion Sims (1862). W piśmiennictwie XIX i początku XX wieku sądzono, że wynika ona z ignorancji kobiet (Faure i Sireday 1909), Por.Z. Lew-Starowicz, Seksuologia sądowa, Warszawa 2000, s. 83.

6 Por. B. WróBel, Ocena występowania bolesnego współżycia u kobiet w praktyce ginekologicznej, Ginekologia Polska 11 (2008), s. 763.

7 Taka nazwa widnieje w Międzynarodowej Statystycznej Klasyfikacji Chorób i Problemów Zdrowotnych ICD-10.

8 Por. Z. Lew-STarowicz, Leczenie czynnościowych zaburzeń seksualnych, Warszawa 1985, s. 188; Z. Lew-StArowicz, A. DŁUgoŁęCKA, Edukacja seksualna, Warszawa 2006, s. 180. 
Pierwsza $\mathrm{z}$ nich jest spowodowana wrodzonymi lub nabytymi brakami anatomicznymi lub problemami organicznymi narządów rodnych. Druga z kolei, polega na zaburzeniach w czynnościach narządów płciowych, przy braku wyraźniejszych zmian anatomicznych w ich obrębie, a przyczyn należy się doszukiwać w psychice kobiety ${ }^{9}$.

W ujęciu kanonicznym jednostka chorobowa, o której mówimy, może stać się przyczyną przeszkody małżeńskiej albo też niezdolności do podjęcia istotnych obowiązków małżeńskich. Kiedy więc waginizm będzie przyczyną nieważności małżeństwa zgodnie z kan. $1084 \mathrm{KPK} ?^{10}$.

\section{Definicja niemocy płciowej}

Aby odpowiedzieć na to pytanie, należy krótko przypomnieć, że waginizm w sensie szerokim i kanonicznym może być przyczyną przeszkody małżeńskiej zwanej niemocą płciową ${ }^{11}$. Przez niemoc płciową w znaczeniu prawa kanonicznego należy rozumieć niezdolność do małżeńskiego obcowania cielesnego, która polega na wrodzonym lub nabytym, szeroko pojętym braku (występującym w tym przypadku po stronie kobiety), uniemożliwiającym akt płciowy z natury zmierzający do zrodzenia potomstwa. Aby zrozumieć uzasadnienie wprowadzenia

\footnotetext{
9 Por. H. Stawniak, Niemoc płciowa jako przeszkoda do małżeństwa, Warszawa 2000, s. 183; tenże, Przeszkoda niemocy płciowej, w: W. GóRALsKi (red.), Przeszkody małżeńskie w prawie kanonicznym, Warszawa 2016, s. 135.

10 Najłatwiej byłoby dokonać prostego podziału i stwierdzić, że waginizm organiczny jest przyczyną powstania przeszkody małżeńskiej, natomiast waginizm psychogenny jest przyczyną niezdolności z przyczyn natury psychicznej do podjęcia istotnych obowiązków małżeńskich z racji jego psychicznej genezy. Niestety takiego uproszczonego podziału nie można dokonać mimo tego, że niektórzy autorzy taki podział sugerują. J. M. Pinto Gómez uważa, że waginizm psychogenny powoduje niezdolność z przyczyn natury psychicznej do podjęcia istotnych obowiązków małżeńskich. Por. H. Stawniak, Niemoc płciowa jako przeszkoda do małżeństwa, dz. cyt., s. 210.

11 Kan. 1084 n. 1 KPK: „Impotentia coeundi antecedens et perpetua, sive ex parte viri sive ex parte mulieris, sive absoluta sive relativa, matrimonium ex ipsa eius natura dirimit”.
} 
tej przeszkody, trzeba przypomnieć, że małżeństwo jest nastawione na rodzenie i wychowywanie potomstwa, co stanowi jego szczytowe uwieńczenie. Impotencji nie można jednak mylić z pojęciem niepłodności, która jako niezdolność do zapłodnienia i poczęcia potomstwa, jako taka nie wzbrania, ani nie powoduje nieważności małżeństwa. Małżonkowie bowiem w takim przypadku są zdolni do współżycia, ale ze względu na istniejącą niepłodność nie dochodzi do poczęcia niezależnie od ich woli. Podstawą istnienia przeszkody impotencji jest prawo Boże naturalne ${ }^{12}$. Dlatego Kościół nie udziela dyspensy od tej przeszkody ${ }^{13}$.

\section{Przymioty niemocy płciowej}

Niezdolność dokonania aktu małżeńskiego winna być uprzednia, trwała, pewna i absolutna lub względna. Pierwszym przymiotem impotencji (w tym przypadku spowodowanej waginizmem) jest więc jej uprzedniość. Rozważa się ją w przeciwieństwie do następczości, która - co istotne - nie może już wpłynąć na ważność małżeństwa. Przez uprzednią należy rozumieć taką, w myśl doktryny i jurysprudencji, która istniała przed i w momencie wyrażania zgody

\footnotetext{
12 W nowo opublikowanej monografii istnieje dość obszerna krytyka takiego postawienia problemu. Autor wprost mówi o błędzie aktualnego kodeksu i wykazuje jego niekonsekwencję przy opisie czym ma być wspólnota małżeńska (kan. 1055 $\$ 1$ ), z dalszymi normami. Ponadto stwierdza się, że prawo dotyczące przeszkody impotencji jest zbyt rygorystyczne i istnieje potrzeba jego zweryfikowania (Moneta), a ponadto zbyt koncentruje się jeszcze na akcie małżeńskim i ujmuje go zbyt biologicznie (Häring). Istnienie tej przeszkody uzasadnia się w prawie małżeńskim naturą małżeństwa. Natura jednak małżeństwa, jak się wydaje, nie wymaga w każdym przypadku zdolności do współżycia (tzw. małżeństwa Józefowe, małżeństwa w podeszłym wieku). H. Stawniak kończąc rozdział poświęcony przeszkodzie niemocy płciowej postuluje uregulowanie problematyki impotentia coeundi w ramach kan. 1098 i tym samym zniesienie tej przeszkody w kanonicznym prawie małżeńskim. Por. H. Stawniak, Przeszkoda niemocy płciowej, dz. cyt., s. 150 -156.

13 Por. J. Krzywкowska, Przeszkoda niemocy płciowej w świetle wykładni kan. 1084 Kodeksu Prawa Kanonicznego z 1983 roku, Studia Prawnoustrojowe 21 (2013), s. 35-37.
} 
małżeńskiej. Uprzedniość „przed” wyrażeniem zgody oznacza, że istniała już w okresie przedślubnym. Z kolei mówiąc „W momencie” wyrażania zgody, podkreśla się, że nawet moment po fakcie zaślubin jest już kwalifikowany jako następczy. Podsumowując, należy stwierdzić, że aby mówić o istnieniu przeszkody niemocy płciowej, należy być przekonanym o jej zaistnieniu przed, a przynajmniej w chwili zawierania umowy małżeńskiej. Oczywiście w przypadku pochwicy najczęściej bardzo trudno jest określić czy choroba była uprzednia czy następcza. W praktyce proponuje się przyjęcie domniemania prawnego. Jeżeli wątpliwość co zdolności osoby do dokonania aktu małżeńskiego nastąpiła wkrótce po celebracji małżeństwa (np. podczas usiłowania skonsumowania go), należy przypuszczać, iż impotencja ta była uprzednia. Natomiast jeśli wątpliwości te pojawiły się po jakimś czasie, to domniemywa się, że impotencja była następcza. Jednak należy pamiętać, że w dowodzeniu procesowym każdy argument przeciwny obala powyższą presumpcję ${ }^{14}$.

Pomocne w tej kwestii staje się rozróżnienie na impotencję organiczną i funkcjonalną, jakiego dokonuje M. F. Pompedda, który zwraca uwagę na to, że w przypadku impotencji organicznej spowodowanej wrodzonymi lub nabytymi brakami anatomicznymi, domniemanie jest zawsze za uprzedniością, z wyjątkiem sytuacji, kiedy przyczyna mająca wpływ na powstanie impotencji zaistniała po fakcie zawarcia wspólnoty życia. W przypadku natomiast impotencji funkcjonalnej, jeżeli ujawnia się ona już w chwili próby pierwszego aktu małżeńskiego i nie trzeba przypisywać jej powstania przyczynie zaistniałej po zawarciu małżeństwa, należy domniemywać, że impotencja była uprzednia ${ }^{15}$.

Konkludując, należy stwierdzić, że niemoc płciowa o charakterze następczym nie stanowi przeszkody, choć może być tytułem

\footnotetext{
14 H. Stawniak, Przeszkoda niemocy płciowej, dz. cyt., s. 136.

15 Tamże. Zob. także, W. Szafrański, Przeszkoda impotencji w prawie kanonicznym, Włocławek 1964, s. 89-91.
} 
wniesienia prośby o dyspensę papieską od małżeństwa ważnie zawartego, jeśli nie zostało ono dopełnione ${ }^{16}$.

Drugim przymiotem impotencji jest jej trwałość. Trudność w definiowaniu tego przymiotu polega m.in. na tym, że inaczej ją definiuje medycyna i inaczej kanonistyka. Z punktu widzenia medycznego jakaś osoba jest dotknięta impotencją w tym momencie i to wystarcza, by powiedzieć, że jest impotentem. Jeśli choroba jest uleczalna, czyli może być przywrócona zdolność do aktów seksualnych, nie jest więc trwała. Z punktu widzenia medycznego ta osoba w tym momencie będzie też impotentem. Inaczej ta kwestia będzie przedstawiała się na płaszczyźnie prawa kanonicznego. Ponieważ impotencja jest fundamentem do zaistnienia przeszkody niemocy płciowej, musi ona być trwała w momencie zawierania małżeństwa, i to trwała w rozumieniu doktryny i jurysprudencji kościelnej ${ }^{17}$.

Ta „trwałość” ma znaczenie techniczno-prawne i wymaga gruntownego wyjaśnienia. Impotencja jest trwała wówczas, gdy nie ma żadnej możliwości jej usunięcia, czyli nie może być wyleczona. Na tym etapie pojęcie kanonistyczne pokrywa się z pojęciem medycznym. Różnica polega na tym, że prawodawca kościelny uznaje impotencję za trwałą również wtedy, gdy może być ona uleczona, ale tylko środkami niegodziwymi lub nadzwyczajnymi, czyli takimi, które sprowadzają się do ingerencji chirurgicznych lub terapii, które są bardzo niebezpieczne dla zdrowia i życia. Podobnie impotencja będzie trwałą wówczas, gdy należałoby użyć do jej leczenia środków ryzykownych, bardzo kosztownych i niedostępnych dla przeciętnego człowieka. Relatywność trwałości niemocy płciowej z jednej strony pokazuje, że przeszkoda impotencji może częściej mieć miejsce u osób w krajach biednych niż bogatych, a z drugiej strony rozwój medycyny i możliwość zastosowana nowoczesnych środków powoduje, że zmniejsza się liczba przypadków impotencji trwałej. Ponadto nie brakuje i takich autorów, którzy twierdzą, że obiektywnie istnieje

16 Por. J. Krzywkowska, Przeszkoda niemocy płciowej w świetle wykładni kan. 1084 Kodeksu Prawa Kanonicznego z 1983 roku, dz. cyt., s. 38.

17 H. Stawniak, Przeszkoda niemocy płciowej, dz. cyt., s. 137. 
tylko impotencja czasowa, a nie ma niemocy płciowej trwałej. Jednak taka opinia może być prawdziwa mając przed oczyma medyczne pojęcie impotencji. W przypadku zaś impotencji rozpatrywanej na płaszczyźnie prawa kanonicznego taka opinia jest nieprawdziwa, ponieważ pojęcie trwałości impotencji jest kwalifikowane z uwzględnieniem konkretnej osoby, miejsca, czasu, nadzwyczajności środków $\mathrm{i}$ ich aspektu etycznego ${ }^{18}$.

Trzecim atrybutem przeszkody impotencji jest jej absolutność lub względność. Wprawdzie jedna i druga jej postać powoduje nieważność małżeństwa, to jednak rozróżnienie jest wskazane nie tylko od strony teoretycznej, lecz także praktycznej. Z bezwzględną postacią niemocy płciowej mamy do czynienia wtedy, gdy osoba nie jest zdolna spełnić aktu seksualnego z jakąkolwiek osobą płci przeciwnej w przeciwieństwie do impotencji względnej, gdzie osoba ta wprawdzie jest zdolna do aktów seksualnych z osobami płci przeciwnej, ale nie jest zdolna do takich aktów w małżeństwie, ze swoim partnerem. W takim przypadku osoba nie jest impotentem z tytułu niemocy absolutnej, ale właśnie względnej. Najczęstszym źródłem tak określonej niemocy płciowej jest przyczyna natury psychicznej lub psychologicznej ${ }^{19}$.

Kolejnym przymiotem impotencji jest jej pewność. Kan. 1084, n. 2 stanowi: „Jeśli przeszkoda niezdolności jest wątpliwa, czy wątpliwość ta jest prawna czy faktyczna, nie należy zabraniać małżeństwa ani też, dopóki trwa wątpliwość, orzekać jego nieważności”. Z przedstawionego fragmentu kodeksowego wynika, że tylko przeszkoda pewna może być egzekwowana w stosunku do niektórych osób, zabraniając stworzenia wspólnoty małżeńskiej. Racja takiego rozwiązania prawnego jest zrozumiała i wystarczająco uzasadniona, gdyż uprawnienie do zawarcia małżeństwa i wybrania sobie współmałżonka jest podstawowym prawem osoby ludzkiej i dlatego norma, dopóki nie będzie pewności moralnej istnienia faktu lub okoliczności, które czynią osobę niezdolną do aktu małżeńskiego, nie może ograniczać tego fundamentalnego prawa. Należy zauważyć, że na korzyść za tak

\footnotetext{
18 Tamże, s. 137-138.

19 Tamże, s. 138.
} 
postawioną tezą przemawia również domniemanie prawne o zdolności każdego mężczyzny i każdej kobiety do aktu małżeńskiego, tym czasem przeszkoda jest brakiem i ograniczeniem prawa. Konkludując, należy zauważyć, że tylko w przypadkach naprawdę pewnych można ograniczyć komuś uprawnienie subiektywne, mające swój fundament w prawie naturalnym, to jest prawo do zawarcia małżeństwa. Prawodawca stoi na stanowisku, że to pewne prawo ma przewagę nad wątpliwym prawem czy faktem, dlatego matrimonium non est impediendum ${ }^{20}$.

\section{Różnorodność diagnoz w kontekście kan. 1084 KPK}

Po koniecznym wstępie dotyczącym przymiotów przeszkody impotencji przejdziemy do omówienia jej rodzajów w kontekście kan. 1084 KPK. Mówiliśmy już wcześniej, że impotencja dzieli się na organiczną i funkcjonalną, dla ogólnego porządku należy jednak stwierdzić ponadto, że niemoc płciową można podzielić na tę po stronie mężczyzny oraz tę po stronie kobiety. W niniejszym studium oczywistym jest fakt, że przedmiotem rozważań ma być impotencja po stronie kobiety, która impotentką będzie wówczas, gdy będzie chorować na waginizm organiczny lub funkcjonalny ${ }^{21}$.

$\mathrm{Na}$ tym etapie rozważań zasadnym wydaje się pytanie: Czy w sytuacji, gdy kobieta choruje na jedną z wyżej wymienionych chorób, zawsze będziemy mieli do czynienia $\mathrm{z}$ jej impotencją $\mathrm{w}$ sensie kanonicznym? Najpierw zajmiemy się waginizmem organicznym, ponieważ tutaj sprawa wydaje się łatwiejsza do rozsądzenia i udzielenia konkretnej odpowiedzi na postawione wyżej pytanie.

\subsection{Brak pochwy i problem pochwy sztucznej}

W powszechnej opinii doktryny i jurysprudencji należy uznać za impotentkę kobietę, która nie ma pochwy (waginizm organiczny),

\footnotetext{
20 Tamże, s. 139-140.

21 Tamże, s. 140-142.
} 
i to zarówno w przypadku, gdy ten brak był z urodzenia czy na skutek zabiegów chirurgicznych, czyli pod wpływem czynników urazowych czy chorobowych. Konieczność pochwy łączono zawsze z elementem istotnym aktu małżeńskiego, w którym to organie dochodzi do połączenia ciał, a szczególna funkcja tego organu polegała na przyjęciu członka męskiego i wsysaniu nasienia ${ }^{22}$.

Sprawa jest więc prosta w sytuacji, gdy stwierdza się brak pochwy ${ }^{23}$, ale co w sytuacji, gdy ten brak zastąpiono pochwą sztuczną? Czy kobieta, która nie miała pochwy od urodzenia lub brak ten nastąpił w późniejszym czasie, a w drodze operacji chirurgicznej wyspecjalizowani chirurdzy utworzyli u niej ten organ w jakikolwiek sposób, jest zdolna, czy raczej należy mówić o jej niezdolności do ważnego zawarcia małżeństwa? Problem ten podejmowali nieliczni kanoniści, choć zagadnienie wydaje się być niezwykle ważne, nie tylko $\mathrm{z}$ racji braku pochwy, ale również $\mathrm{z}$ racji w ostatnich latach coraz częstszych przypadków tzw. zmiany płci. Trzeba zauważyć, że nie ma zgodności wśród autorów podejmujących ten ważki problem, co do możliwości zaistnienia przeszkody impotencji ze względu na sztuczną pochwę. Jednak większość wyraziła opinię, że operacja taka dokonana przed ślubem nie powoduje niezdolności do małżeństwa, gdy jest możliwy akt seksualny. Jeśli natomiast operacja

\footnotetext{
22 Tamże, s. 142-143.

23 Wrodzony brak pochwy spowodowany jest najczęściej aplazją (niewykształceniem się mimo powstania zawiązku) przewodów Müllera (z których rozwijają się żeńskie narządy płciowe), bardzo rzadko zaś agenezją (brak narządu wraz z zawiązkiem). W obu przypadkach natomiast współistnieje z brakiem czynnej macicy. Brak pochwy może być również kliniczną manifestacją atrezji (zarośnięcia) pochwy. Szacunkowa częstość występowania wad pochwy wynosi 1 na 4-20 tysięcy noworodków płci żeńskiej. Wady te są drugą, po dysgenezji gonad, przyczyną pierwotnego braku miesiączki. Wrodzony brak pochwy najczęściej występuje w postaci zespołu Mayera-Rokitansky’ego-Küstnera i Hausera, w którym brak pochwy stanowi konsekwencję aplazji przewodów Müllera i jest skojarzony z brakiem macicy, obecnością macicy szczątkowej albo obecnością szczątkowych rogów macicy przy bocznych ścianach miednicy. Por. Z. Friebe, K. Kapczuk, Wady wrodzone żeńskich narządów płciowych, w: G.H. BRĘBOw ICz, Położnictwo i ginekologia, t. 2, Warszawa 2013, s. 593-597.
} 
nastąpiła po zawarciu ślubu, to małżeństwo jest nieważne i można je konwalidować. Opinia ta w ogólności ma związek z przekonaniem wielu kanonistów, którzy w materii zwracają uwagę na wspomniany rodzaj operacji chirurgicznej odróżniając środki zwyczajne, godziwe i bezpieczne dla zdrowia i życia, od środków nadzwyczajnych, niegodziwych i niebezpiecznych. Jeśli chodzi o pierwszy przypadek, skoro dokonano operacji, to niezależnie od tego jakich środków użyto, kobieta jest zdolna do aktu małżeńskiego, czyli małżeństwo jest ważne. Należy jednak zwrócić uwagę na to, że w tym przypadku akcentuje się tylko wymiar pełnego rozumienia tego aktu, a także to, że pomija się cały wymiar pełnego rozumienia tego aktu, a także pomija się kwestię spełniania wymogów prawnych co do narządów kobiecych, w łączności z dyskutowaną w nauce kwestią skierowania aktu małżeńskiego „przez się” do zrodzenia potomstwa. W drugim przypadku sprawa również nie jest jednoznaczna. Małżeństwo mogło być zawarte nieważnie, gdyż istniała przeszkoda niemocy płciowej trwała z punktu widzenia prawa kanonicznego. Osoba poddająca się operacji kosztownej i nadzwyczajnej przestała być impotentem w sensie kanonicznym, bo przeszkoda ustała i dlatego małżeństwo może być uważnione ${ }^{24}$.

Istotną, w powyższym sporze, jest odpowiedź Kongregacji Sakramentów, udzielona biskupowi diecezji kanadyjskiej z dnia 1 sierpnia 1972 r., w której stwierdzono, że niewystarczająca jest pochwa skonstruowana $\mathrm{z}$ materiału plastycznego, ilekroć nie jest zdolna do normalnego aktu małżeńskiego, który sam z siebie skierowany jest do zrodzenia potomstwa. $Z$ tych faktów wynika, że przy sztucznej pochwie istnieje pewność o istnieniu przeszkody niemocy płciowej. Nie można więc takiej kobiecie, a tym bardziej mężczyźnie chcącym zmienić płeć, pozwolić na zawarcie małżeństwa ${ }^{25}$.

\footnotetext{
24 H. Stawniak, Przeszkoda niemocy płciowej, dz. cyt. s. 143-144.

25 Tamże, s. 145. Por. G. DzIERżon, Wpływ organicznej impotencji kobiecej na nieważność małżeństwa w świetle wyroku Roty Rzymskiej c. P.V. Pinto z 27.10.1995 r., Ius Matrimoniale 5 (2000), s. 214.
} 
Podsumowując, należy stwierdzić, że zawsze, ilekroć występuje u kobiety brak pochwy ${ }^{26}$, a w rozpoznaniu klinicznym znajdujemy tzw. aplazję lub agenezję, bez względu na to czy brak ten zastąpiono pochwą sztuczną czy też nie, kobieta jest impotentką, a małżeństwo przez nią zawarte (przy spełnieniu warunków uprzedniości, trwałości i pewności) jest nieważne. Podobnie wydaje się mieć sprawa $z$ atrezją, gdzie pochwa występuje, ale jest ona całkowicie zarośnięta.

\subsection{Niedorozwój pochwy i jej nadmierna ciasnota}

Analogicznie rozstrzygnięta została sprawa niedorozwoju i nadmiernej ciasnoty pochwy, wówczas gdy niemożliwe było normalne współżycie małżonków. Wprawdzie mogła zachodzić wówczas impotencja absolutna lub względna. Ale też a priori nie da się stwierdzić w takim przypadku o niezdolności do aktu małżeńskiego. Nie można też orzekać o nieważności małżeństwa $\mathrm{z}$ tytułu omawianej w tym przypadku przeszkody. Można natomiast mówić o niemocy płciowej instrumentalnej u kobiety w przypadku pochwy infantylnej, kiedy ten organ nie jest zdolny do przyjęcia członka męskiego i nasienia. Niedorozwój bowiem uniemożliwia zwykle penetrację, a ta stanowi istotny element aktu małżeńskiego. Gdyby jednak chodziło o sytuację, gdy pochwa jest zamknięta od strony wewnętrznej, np. z powodu usunięcia macicy, jajowodów i jajników, nie zachodzi u kobiety przeszkoda niemocy płciowej, a ma miejsce tylko jej niepłodność ${ }^{27}$.

\footnotetext{
26 W aspekcie psychologicznym brak pochwy i macicy, uniemożliwiający normalne współżycie i posiadanie potomstwa, jest niezwykle trudny do zaakceptowania przez kobietę. Zwykle po wstępnym szoku następuje przedłużony okres depresji. Pacjentki mają poczucie mniejszej wartości, kwestionują swoją kobiecość, wątpią w możliwość związania heteroseksualnego. Por. Z. Friebe, K. Kapczuk, Wady wrodzone żeńskich narządów płciowych, dz. cyt., s. 598.

27 Por. H. Stawniak, Przeszkoda niemocy płciowej, dz. cyt., s. 145-146.
} 


\subsection{Poprzeczne i podłużne przegrody pochwy}

Kolejną grupą z wad organicznych kobiety, mogących powodować u niej przeszkodę niemocy płciowej, są poprzeczne $e^{28}$ i podłużne ${ }^{29}$ przegrody pochwy z zarośnięciem błony dziewiczej włącznie. Wydaje się jednak, że tego typu wady nie powodują przeszkody niemocy płciowej u kobiety z racji tego, że zwykle nie są one trwałe. Da się je usunąć za pomocą nieinwazyjnej operacji chirurgicznej ${ }^{30} \mathrm{i}$ w tym przypadku należy mówić raczej o niemocy czasowej lub uleczalnej ${ }^{31}$.

Podsumowaniem części dotyczącej wpływu waginizmu organicznego jako przyczyny niemocy płciowej mogą stać się potwierdzające powyższe ustalenia słowa G. Dzierżona, który idąc tokiem rozumowania

${ }^{28}$ Poprzeczne przegrody są zarośnięciami narządów płciowych na niewielkiej długości, poprzecznie zamykającymi ich światło. Zarośnięcia te mogą być wrodzone lub też nabyte, które są wynikiem procesów chorobotwórczych toczących się w obrębie narządów płciowych. Do najczęstszych z nich zaliczyć można stany zapalne prowadzące do uszkodzenia nabłonka pokrywającego narządy i zaburzenia hormonalne doprowadzające poprzez zmniejszenie odporności błony śluzowej pochwy do wystąpienia zapaleń i owrzodzeń. Por. Sz. BANASZEwsKI, Wady wrodzone narządów płciowych i ich następstwa, w: T. PISARSKI, Położnictwo i ginekologia, Podręcznik dla studentów, Warszawa 2002, s. 42. Przegrody te zlokalizowane są najczęściej na granicy górnej i środkowej 1/3 długości pochwy. Przegrody mogą być pełne, zamykające całkowicie światło pochwy, lub częściowe, z niewielkim otworem pośrodku. Takie przegrody mogą utrudniać, a nawet uniemożliwiać normalne współżycie. Przegrody częściowe nie dają zwykle żadnych objawów ponieważ otwór umożliwia odpływ wydzielin pochwy i krwi miesiączkowej. Natomiast w przypadku przegród całkowitych lub zarośnięcia błony dziewiczej powyżej poziomu przegrody, na skutek gromadzenia się krwi miesiączkowej, rozwija się krwiak zastoinowy. Por. Z. FriebE, K. KAPCZUK, Wady wrodzone żeńskich narząów płciowych, dz. cyt., s. 599.

${ }^{29}$ Przegrody podłużne występują najczęściej na całej długości światła pochwy w wyniku czego mówimy o pochwie całkowicie przegrodzonej lub podwójnej. Por. Sz. BANASZEWSKI, Wady wrodzone narządów płciowych i ich następstwa, dz. cyt., s. 41.

${ }^{30}$ Por. Z. Friebe, K. KapCZuK, Wady wrodzone żeńskich narządów płciowych, dz. cyt. s. 600.

31 Por. K. Graczyк, Aspekty medyczno-prawne impotencji względnej i psychiatrycznej, Studia Włocławskie 8 (2005), s. 314. 
M. Pompeddy, stwierdza, że o impotencji kobiety można mówić wówczas, gdy istnieje jedna $\mathrm{z}$ trzech sytuacji: brak pochwy, zbyt małe jej rozmiary lub niedostępność do niej. Te anomalie organiczne uniemożliwiają bowiem dokonanie naturalnej penetracji przez mężczyznę $e^{32}$.

\section{Waginizm psychogenny}

Po omówieniu wad organicznych powodujących waginizm przejdźmy teraz do rozważań na temat waginizmu psychogennego ${ }^{33}$ i jego wpływu na powstanie przeszkody niemocy płciowej. Już z samej definicji wynika, że choroba ta może powodować lub nie przeszkodę $\mathrm{z}$ racji tego, że „uniemożliwia lub utrudnia przeniknięcie penisa do pochwy" ${ }^{\prime 4}$. W pierwszym przypadku nie ma wątpliwości, że ma miejsce przeszkoda impotencji, ponieważ kobieta nie posiada zdolności do współżycia małżeńskiego, uniemożliwiając penetrację przez mężczyznę i powodując tym samym brak możliwości przyjęcia ejakulatu ${ }^{35}$. W drugim natomiast przypadku sytuacja nie jest już taka prosta i klarowna ${ }^{36}$.

32 Por. G. DzIERżon, Wpływ organicznej impotencji kobiecej na nieważność małżeństwa w świetle wyroku Roty Rzymskiej c. P.V. Pinto z 27.10.1995 r, dz. cyt., s. 213-214. ${ }^{33}$ Obszerną i precyzyjną definicję pochwicy zamieścił w swojej książce wybitny seksuolog S. Kratchvil, wg niego „Waginizm to odruchowe, kurczowe ściągnięcie mięśni wejścia do pochwy i innych mięśni dna miednicy, które uniemożliwiają lub utrudniają przeniknięcie penisa do pochwy. Ma charakter odruchu obronnego, który wywoływany jest realną, oczekiwaną lub tylko wyobrażaną próba penetracji. Niekiedy dołącza się też odruchowe ściskanie ud i wygięcie kręgosłupa jak przy opistotonii. Zwykle zjawisko to łączy się z fobią, dotyczącą defloracji, stosunku płciowego czy jakiejkolwiek penetracji waginalnej”. Por. S. KRATOCHVIL, Leczenie zaburzeń seksualnych, Warszawa 2002, s. 125.

34 Tamże; M. BeISERT, Psychologia zaburzeń seksualnych, w: H. SĘK (red.), Psychologia kliniczna, Warszawa 2014, s. 219.

35 Por. W. Góralski, Małżeństwo kanoniczne, Warszawa 2011, s. 113.

36 Można by pójść w refleksji dwiema drogami, o których pisze S. Paździor w swojej publikacji Przyczyny psychiczne niezdolności osoby do zawarcia małżeństwa $w$ świetle kan. 1095, Lublin 1999, s. 287, ale będzie to już przedmiotem naszych rozważań w drugiej części artykułu. 
Rozważając problematykę przeszkody niemocy płciowej z powodu waginizmu psychogennego nie sposób nie wspomnieć o tym, że w literaturze medycznej znajdujemy zapis informujący o tym, że waginizm pierwotny zwykle uniemożliwia jakąkolwiek penetrację, w przeciwieństwie do wtórnego, gdzie możliwa jest tolerancja na pewne rodzaje penetracje ${ }^{37}$. Sytuacja wydaje się więc być podobna do tej opisanej wyżej.

$\mathrm{W}$ literaturze medycznej znajdujemy również opis czterech stopni zaawansowania waginizmu ${ }^{38}$ : przypadki najtrudniejsze, ciężkie, mniej trudne i lekkie ${ }^{39}$. W pierwszych trzech przypadkach mamy do czynienia z sytuacją, gdy kobieta z pewnością nie jest zdolna do współżycia i przyjęcia ejakulatu, a więc istnieje przeszkoda niemocy płciowej, w czwartym natomiast, sytuacja może wyglądać dwojako: albo jest zdolna, albo nie.

Do podobnych wniosków dochodzi też H. Stawniak, który za medykami dokonuje podziału pochwicy na wyższą i niższą. Przy wyższej członek męski może być wprowadzany in vaginam mulieris, ale z trudem i bólem stamtąd jest wyprowadzany. Przy pochwicy niższej już samo wprowadzenie członka jest wręcz niemożliwe i wtedy mamy do czynienia z impotencją funkcjonalną, o ile stan ten jest trwały ${ }^{40}$.

\footnotetext{
37 Por. M. StefankiewiCz, S. ŚLĄSKi, Diagnoza zaburzeń seksualnych u kobiet adaptacja testu, Studia Psychologica 10 (2010), s. 322.

38 Wyróżnia się cztery stopnie w określeniu zaawansowania waginizmu. Według Arentewicza i Schmidta w przypadkach najtrudniejszych nawet badania ginekologiczne są niemożliwe i aby je wykonać należy pacjentkę uśpić. W przypadkach ciężkich jest niemożliwe wprowadzenie palca. W mniej trudnych można wprowadzić palec, ale w żadnym wypadku penisa. W przypadkach lekkich wprowadzenia penisa jest niekiedy możliwe, ale zawsze okazuje się bolesne. Por. S. KRATOCHVIL, Leczenie zaburzeń seksualnych, dz. cyt., s. 126; E. MaŁACHOWsкA, S. Jaкima, Cechy osobowości partnerów w związkach nieskonsumowanych, Seksuologia Polska 5 (2007), s. 42. W pierwszych dwóch przypadkach zdecydowanie mamy do czynienia z pochwicą absolutną, jeśli chodzi o przypadek trzeci w odniesieniu do aktu małżeńskiego, pochwica jest również absolutna, natomiast przypadek czwarty dotyczy pochwicy względnej, uwarunkowanej innymi czynnikami. Por. Z. LEw-STArowicz, Zaburzenia seksualne, w: Z. Lew-Starowicz, V. Skrzypulec (red.), Podstawy seksuologii, Warszawa 2010, s. 189).

39 Por. Z. Lew-Starowicz, Zaburzenia seksualne, dz. cyt., s. 189.

40 Por. H. Stawniak, Przeszkoda niemocy płciowej, dz. cyt., s. 148.
} 
W sytuacji więc pochwicy wyższej nie zachodzi przeszkoda niemocy płciowej, a raczej sytuacja mieszcząca się w kan. 1095 n. 3 KPK.

Analizując literaturę psychologiczno-medyczną dotyczącą waginizmu psychogennego, łatwo zauważyć, że osoby specjalizujące się w leczeniu tej choroby zgodnie twierdzą, że pochwica tego typu jest zaburzeniem wysokiej skuteczności leczenia, sięgającej 80\% przypadków, a niektórzy, jak Kratochvil ${ }^{41}$ czy Lew-Starowicz, uważają, że skuteczność ta sięga nawet $100 \%{ }^{42}$. Najbardziej istotnym w skutecznym leczeniu jest motywacja samej pacjentki i jej osobista decyzja ukierunkowana na podjęcie szeroko podjętej terapii i ćwiczeńn ${ }^{43}$.

Zasadnym będzie w tym miejscu pytanie, czy istnieje rozbieżność w definicji trwałości pochwicy psychogennej u medyków i kanonistów? Wydaje się bowiem, że leczenie ${ }^{44}$, które polega na farmakoterapii, psychoterapii czy treningach nie powinno być i nie jest nadzwyczajne, kosztowne, niebezpieczne dla zdrowia i życia, a nawet ryzykowne. Trudno więc mówić o trwałości tej choroby. Choć w niektórych sytuacjach, przy tak postawionej tezie, problemu może nastręczać godziwość niektórych z proponowanych metod terapii (np. używanie tzw. dylatorów ${ }^{45}$ czy wibratorów ${ }^{46}$ ).

41 Por. S. Kratochvil, Leczenie zaburzeń seksualnych, dz. cyt., s. 131.

42 Por. Z. Lew-Starowicz, Seksuologia sądowa, Warszawa 2000, s. 84.

43 Por. S. Kratochvil, Leczenie zaburzeń seksualnych, dz. cyt., s. 129.

44 W leczeniu zaleca się farmakoterapię (leki przeciwbólowe, rozkurczające, przeciwlękowe), metody chirurgiczne polegające na defloracji, desensybilizację, hipnozę i psychoterapię indywidulaną. Szczególne jednak uznanie i rozpowszechnienie zyskały metody treningowe, których skuteczność jest najwyższa, a czas leczenia krótszy w porównaniu z innymi metodami psychoterapii. Por. Z. LEw-STARowicz, Leczenie nerwic seksualnych, Warszawa 1991, s. 205.

45 Do wykonywania ćwiczeń polegających na rozszerzeniu pochwy stosuje się tzw. dylatory, gładkie zwężające się na końcu rurki o różnych rozmiarach. Do ćwiczeń należy stopniowo wprowadzać samego mężczyznę. Jeżeli tylko ćwiczenia będą skuteczne, mężczyzna może spróbować ostrożnej penetracji. Por. M. Jones, Zaburzenia seksualne, w: J. Rүвакошsкі, F. Rүвакошsкі (red.), Psychiatria, t. 2, Wrocław 2005, s. 394.

46 Według znanego seksuologa metoda treningowa, która obok leków i psychoterapii, względnie metody chirurgicznej, jest bardzo skuteczna powinna składać się 


\section{Podsumowanie}

Podsumowując opinie o wysokim odsetku skutecznego leczenia pochwicy nieorganicznej, nie sposób nie zgodzić się z opinią D’Advacka, który pisał wprost o zmierzchu istnienia przeszkody niemocy płciowej ${ }^{47}$. A można iść i o krok dalej, za wcale nieodosobnionymi autorami, którzy głoszą, że z racji rozwoju medycyny i możliwości zastosowania nowoczesnych środków, zmniejsza się liczba impotencji trwałej. Niektórzy mówią nawet, że obiektywnie istnieje tylko impotencja czasowa, a nie ma niemocy płciowej trwałej. Choć z taką opinią trudno się zgodzić na płaszczyźnie definicji trwałości impotencji na sposób kanoniczny ${ }^{48}$.

Podsumowując, rozważania nad kan. 1084 KPK prowadzą do wniosku, że kwalifikacja trwałości przeszkody impotencji w aplikacji do waginizmu czy to organicznego, czy funkcjonalnego należy do trudnych zadań biegłych, a później sędziego kościelnego. Dlatego też niezwykle istotnym, a nawet koniecznym jest występowanie w tych dziedzinach biegłych ${ }^{49}$.

z następujący etapów: edukacja seksualna, nauka kontrolowania mięśni pochwy, relaksacja, kontrolowana penetracja pochwy palcem, później dildo lub wibratorem, a następnie penetracja właściwa podczas aktu seksualnego. Por. Z. LEW-STARowicz, A. DŁugoŁęCKa, Edukacja seksualna, s. 181.

47 Por. H. Stawniak, Przeszkoda niemocy płciowej, dz. cyt. s. 151.

48 Tamże, s. 138.

49 Tamże, s. 150. Zob. także T. Rozkrut, Komentarz do Instrukcji procesowej „Dignitas connubii”, Sandomierz 2007, s. 279. Por. A. GoŁĘBıowskA, Opinia biegłego sądowego i analiza prawna przyczyn niezdolności do zawarcia małżeństwa (kan. 1095 KPK z 1983), Warszawa 2008, s. 146. 


\section{Vaginismus as the marital impediment (can. 1084 CIC of 1983)}

\section{Summary}

Sexual disorders of women are a broad problem contended by many specialists of different disciplines. Vaginismus is one of the diseases of this type. It is a disorder hampering or making the sexual intercourse impossible. By virtue of the cause, it may appear in two types: as organic and inorganic i.e. psychogenic vaginismus.

On the basis of the canon law a vaginismus can become a cause of the marital impediment or the inability for assuming substantial conjugal duties. In case of organic vaginismus (always when woman lacks vagina), whether or not this lack was replaced with the artificial vagina or not, the woman shall be recognized as impotent. Thus, marriage entered by her (assuming that the requirements of pre-existence, permanence and certainties are met) is void. The same applies to the case of the underdevelopment of the vagina.

However, talking about psychogenic vaginismus the distinction shall be made between their different stages (most difficult, heavy, less difficult and light cases). In first three cases we are dealing with the situation when the woman certainly isn't able to co-exist and to accept ejaculate. Therefore, an obstacle of impotence exists. In fourth however, the situation can look in two ways depending on the individual case.

Irrespective of that, by virtue of the high percentage of vaginismus effective curing, some of the specialists indicate that nowadays the existences of impotence obstacle is in decline. 